\title{
Mortality and cancer incidence among workers in an abrasive manufacturing industry
}

\author{
C EDLING,,$^{2}$ B JÄRVHOLM, ${ }^{3}$ L ANDERSSON, ${ }^{2}$ O AXELSON ${ }^{2}$
}

From the Department of Occupational Medicine, ${ }^{1}$ University Hospital, S-75185 Uppsala, Department of Occupational Medicine, ${ }^{2}$ University Hospital, S-58185 Linköping, and Department of Occupational Medicine, ${ }^{3}$ Sahlgrenska sjukhuset, S-41266 Gothenburg, Sweden

ABSTRACT Earlier epidemiological studies have shown that exposure to aluminium oxide and silicon carbide might carry with it an increased risk of lymphomas, stomach cancer, and non-malignant respiratory disease. To elucidate further this possible hazard, the cancer morbidity and the total mortality pattern was studied among 521 men manufacturing abrasive materials who had been exposed to aluminium oxide, silicon carbide, and formaldehyde. Total dust levels were in the range of $0 \cdot 1-1 \cdot 0 \mathrm{mg} / \mathrm{m}^{3}$. The cohort was followed up from 1958 until December 1983 . No significant increase was found in total mortality, cancer mortality, or incidence of non-malignant respiratory diseases.

Aluminium oxide $\left(\mathrm{Al}_{2} \mathrm{O}_{3}\right)$ and carborundum $(\mathrm{SiC})$ are commonly used in industry as grinding materials and both have for long been regarded as biologically inert. In 1980, however, Sparks and Wegman reported an increased incidence of stomach cancer among 931 jewellery workers mainly occupied with polishing. ${ }^{1}$ Furthermore, Wegman and Eisen found an increased risk of non-malignant respiratory disease, in particular pneumonia and silocosis, among 968 male employees of a company producing synthetic abrasive products. ${ }^{2}$ They also found a significant increase of cancers of the digestive organs and of Hodgkin's lymphoma. In a small cohort study (86 men) Järvholm et al reported four deaths from stomach cancer among polishers, compared with 0.4 expected. ${ }^{3}$ The mortality for other causes of death was not increased.

In 1980 two cases of lymphoma in a Swedish company manufacturing abrasive materials were reported to the factory inspectorate. In view of this observation and the above mentioned reports the present study was initiated at the plant where the lymphomas had occurred. Its objective was to investigate if exposure to grinding materials in this factory could have caused an excess of cancers, especially lymphomas and cancers of the gastrointestinal tract; the possibility of an increased risk of non-malignant respiratory diseases was also of interest.

Accepted 13 May 1986

\section{Subjects and methods}

The company in which the study was carried out was founded in 1913, and has today about 500 employees. The study was of a cohort design with a comparison of the cancer morbidity and mortality with that of the general population. Complete personnel files were available from about 1955 . These files were used to identify a cohort of men with at least five years employment some time between 1955 and 1983. A total of 911 individuals were enrolled; 211 were women, both in administration and production, and of the 700 men, 521 were blue collar workers. All individuals were traced through the official registers and followed up until 31 December 1983 if not dead or emigrated before that date. Seven men had emigrated and eight could not be traced; all were blue collar workers. The loss to follow up was thus about $2 \%$ in total or $3 \%$ for the blue collar workers.

Information about mortality and cancer morbidity was collected through the National Death Register and the National Cancer Register, respectively. Only the underlying cause of death was considered and a restriction was made by excluding ages above 74 as the diagnostic validity is likely to decrease at higher ages. The observation periods were $1958-83$ for mortality and 1958-81 for cancer morbidity, the reason for the difference in the observation period being the lack of cancer incidence data after 1981. Expected incidences were calculated with the person-year method using incidence rates for the general popu- 
lation, stratified for age, calendar year, and gender, for which procedure the EPILIN program was used. ${ }^{4}$

\section{EXPOSURE}

The company principally manufactured grinding wheels using aluminium oxide and silicon carbide as abrasives. The abrasives were bound with clay or phenol formaldehyde resins; fillers were also used. Dust measurements had been undertaken since the early 1970s and the exposure of the workers could be divided into heavy or low exposure to abrasives. Heavy exposure refers to an estimated total dust exposure of $5 \mathrm{mg} / \mathrm{m}^{3}$ or more; low means less than $5 \mathrm{mg} / \mathrm{m}^{3}$. The concentrations were often about $1 \mathrm{mg} / \mathrm{m}^{3}$ in the jobs with low exposure. In a few operations there was also exposure to silica at about $0 \cdot 1 \mathrm{mg} / \mathrm{m}^{3}$. During the manufacture of grinding wheels bound by formaldehyde resins, there was a moderate exposure to formaldehyde $\left(0 \cdot 1-1 \mathrm{mg} / \mathrm{m}^{3}\right)$. Fifty nine workers had manufactured abrasive belts. They had had a low exposure to abrasives but an intermittent, heavy exposure to formaldehyde with peaks up to $20-30 \mathrm{mg} / \mathrm{m}^{3}$.

\section{Results and discussion}

No significant increase was found in mortality or in cancer morbidity among the blue collar workers (tables 1 and 2). For the administrative personnel also there was a reasonably close agreement between observed and expected, 19 observed deaths versus 25.8 expected; for cancer the corresponding figures were 8 versus $6 \cdot 2$. The pattern was similar for the⿳亠े⿵冂卄 small group of women. Among the blue collar work ers were four cases of non-malignant respiratory dis eases (pneumonia (1), chronic bronchitis (2), and asthma (1)). By contrast to Wegman and Eisen ${ }^{2}$ wef found no case of silicosis. Two of the four cases ofon respiratory disease had occurred in men with heavy exposure and the expected number in this group was 1.0 . We could find no increased incidence of gastro-so intestinal cancer and with a power of $80 \%$ and $p=\overrightarrow{0}$ 0.05 (one tailed) the study excludes a more than two- $-\overrightarrow{-}$ fold risk of this type of cancer. There were also the two cases of lymphomas (non-Hodgkin), the occur-o rence of which had been one of the reasons for ini- 3 tiating this study. In this population one case only would have been expected so that numerically the ${ }^{\triangleright}$ incidence is doubled. The small number of cases and $\vec{c}$ the prior knowledge about them makes the association inconclusive, however. The increased risk of lymphoma found by Wegman and Eisen related to Hodgkin's lymphoma, whereas they found a PMR of 77 for non-Hodgkin's lymphoma. In the present study a non-significant excess of multiple myeloma, $2 \frac{2}{<}$ observed versus 0.5 expected, was found. The combi- $\overrightarrow{0}$ nation of lymphoma (ICD 200-202) with multipleo0 myeloma (ICD 203) gives a rate ratio of 2.7 with a $95 \%$ confidence interval of $0 \cdot 7-6 \cdot 8$. Thus, combiningo the findings in our study and the study of Wegman and Eisen, any increased risk of lymphomas associated with exposure to abrasives is questionable.

There was no association between the degree of exposure to formaldehyde and cancer. One case of

Table 1 Mortality among male blue collar workers in 1958-83 (7011.5 person-years)

\begin{tabular}{|c|c|c|c|c|}
\hline Cause & Observed & Expected & Obs/exp & $95 \% \mathrm{Cl}^{*}$ \\
\hline $\begin{array}{l}\text { All } \\
\text { Cancer }(140-209) \dagger \\
\text { Respiratory diseases }(460-519) \\
\text { Cardiovascular diseases }(390-458) \\
\text { Accidents, etc }(800-994)\end{array}$ & $\begin{array}{r}79 \\
17 \\
4 \\
42 \\
6\end{array}$ & $\begin{array}{r}79 \cdot 6 \\
18 \cdot 3 \\
3 \cdot 2 \\
38 \cdot 4 \\
7 \cdot 6\end{array}$ & $\begin{array}{l}0.99 \\
0.93 \\
1 \cdot 3 \\
1 \cdot 1 \\
0.79\end{array}$ & $\begin{array}{l}0 \cdot 8-1 \cdot 2 \\
0 \cdot 5-1 \cdot 5 \\
0 \cdot 3-3 \cdot 2 \\
0 \cdot 8-1 \cdot 5 \\
0 \cdot 3-1 \cdot 7\end{array}$ \\
\hline
\end{tabular}

*95\% Confidence interval of the rate ratio (obs/exp).

†International Classification of Diseases, 8 th revision.

Table 2 Incidence of cancer among male blue collar workers between 1958 and 1981

\begin{tabular}{|c|c|c|c|c|}
\hline Site & Observed & Expected & Obs/exp & $95 \% \mathrm{Cl}^{*}$ \\
\hline $\begin{array}{l}\text { All } \dagger \\
\text { Stomach }(151)+ \\
\text { Colon }(153) \\
\text { Pancreas }(157) \\
\text { Lung }(162) \\
\text { Prostate (185) } \\
\text { Lymphoma (200-202) } \\
\text { Multiple myeloma (203) }\end{array}$ & $\begin{array}{r}24 \\
2 \\
2 \\
2 \\
2 \\
4 \\
2 \\
2\end{array}$ & $\begin{array}{r}28 \cdot 5 \\
2 \cdot 5 \\
2 \cdot 0 \\
1 \cdot 1 \\
3 \cdot 5 \\
4 \cdot 7 \\
1 \cdot 0 \\
0 \cdot 5\end{array}$ & $\begin{array}{l}0.84 \\
0.80 \\
1.0 \\
1 \cdot 8 \\
0.57 \\
0.85 \\
2 \cdot 0 \\
4 \cdot 0\end{array}$ & $\begin{array}{l}0 \cdot 5-1 \cdot 3 \\
0 \cdot 1-2 \cdot 9 \\
0 \cdot 1-2 \cdot 9 \\
0 \cdot 2-6 \cdot 6 \\
0 \cdot 1-2 \cdot 1 \\
0 \cdot 2-2 \cdot 2 \\
0 \cdot 2-7 \cdot 2 \\
0 \cdot 5-14 \cdot 4\end{array}$ \\
\hline \multicolumn{5}{|c|}{$\begin{array}{l}\text { *95\% Confidence interval of the rate ratio (obs/exp). } \\
+ \text { In addition to the sites mentioned, there were: lip cancer (1), cancer of the nasopharynx (1), cancer of the small intestine (1), renal cancer (1) } \\
\text { cancer of the urinary bladder (1), skin cancer }(1) \text {, thyroid cancer (1), and cancer of the nervous system (1). } \\
+ \text { International Classification of Diseases, } 8 \text { th revision. }\end{array}$} \\
\hline
\end{tabular}


cancer in the nasopharynx had a low exposure $\left(<0.1 \mathrm{mg} / \mathrm{m}^{3}\right)$ and a relatively short ( 5 years) exposure to formaldehyde.

In summary, this study shows no evidence for an increased mortality or cancer morbidity associated with the manufacturing of abrasives. The study did not, however, have the power to exclude a moderately increased incidence of cancer of certain sites or of mortality from certain causes. The good agreement between the number of observed and expected cases among the administrative employees, with the customary healthy worker effect being noted, may be taken as a check of the validity of the methods of the study since no alteration in mortality would be expected in this group.

\section{References}

1 Sparks PJ, Wegman DH. Cause of death among jewellery workers. J Occup Med 1980;22:733-6.

2 Wegman DH, Eisen E. Causes of death among employees of a synthetic abrasive product manufacturing company. J Occup Med 1981;11:748-53.

3 Järvholm B, Thiringer G, Axelson $\mathrm{O}$. Cancer morbidity among polishers. $\mathrm{Br} J$ Ind Med 1982;39:196-7.

4 Anjou CG, Andersson K, Axelson O, Edling C, Samuelsson PJ, Wigertz O. A computer system for occupational health epidemiology. In: Gremy F, Deqoulet $\mathrm{P}$, Barber B, Salamon R, eds. Medical informatics Europe 81, Toulouse, France. Berlin: Springer Verlag, 1981:734-44.

\section{Vancouver style}

All manuscripts submitted to the $B r J$ Ind Med should conform to the uniform requirements for manuscripts submitted to biomedical journals (known as the Vancouver style)

The $\mathrm{Br} J$ Ind Med, together with many other international biomedical journals, has agreed to accept articles prepared in accordance with the Vancouver style. The style (described in full in $\mathrm{Br}$ Med J, 24 February 1979, $\mathrm{p} \mathrm{532)}$ is intended to standardise requirements for authors.

References should be numbered consecutively in the order in which they are first mentioned in the text by Arabic numerals above the line on each occasion the reference is cited (Manson ${ }^{1}$ confirmed other reports ${ }^{2-5} \ldots$.). In future references to papers submitted to the $\mathrm{Br} J$ Ind Med should include: the names of all authors if there are six or less or, if there are more, the first three followed by $e t$ al; the title of journal articles or book chapters; the titles of journals abbreviated according to the style of Index Medicus; and the first and final page numbers of the article or chapter.

Examples of common forms of references are:

1 International Steering Committee of Medical Editors. Uniform requirements for manuscripts submitted to biomedical journals. $B r$ Med J 1979;1:532-5.

2 Soter NA, Wasserman SI, Austen KF. Cold urticaria: release into the circulation of histamine and eosino-phil chemotactic factor of anaphylaxis during cold challenge. $N$ Engl J Med 1976;294:687-90.

3 Weinstein L, Swartz MN. Pathogenic properties of invading micro-organisms. In: Sodeman WA Jr, Sodeman WA, eds. Pathologic physiology: mechanisms of disease. Philadelphia: W B Saunders, 1974:457-72. 